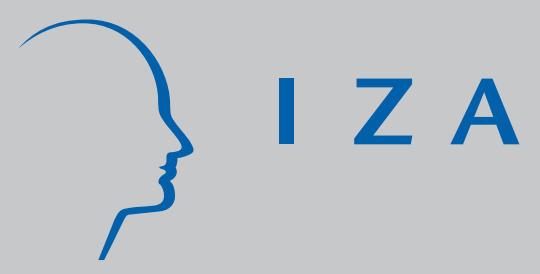

IZA DP No. 4079

How a Mandatory Activation Program Reduces Unemployment Durations: The Effects of Distance

Brian Krogh Graversen

J an C. van Ours

March 2009 


\title{
How a Mandatory Activation Program Reduces Unemployment Durations: The Effects of Distance
}

\author{
Brian Krogh Graversen \\ Danish National Centre for Social Research \\ Jan C. van Ours \\ CentER, Tilburg University, \\ University of Melbourne, CEPR and IZA
}

Discussion Paper No. 4079

March 2009

\author{
IZA \\ P.O. Box 7240 \\ 53072 Bonn \\ Germany \\ Phone: +49-228-3894-0 \\ Fax: +49-228-3894-180 \\ E-mail: iza@iza.org
}

\begin{abstract}
Any opinions expressed here are those of the author(s) and not those of IZA. Research published in this series may include views on policy, but the institute itself takes no institutional policy positions.

The Institute for the Study of Labor (IZA) in Bonn is a local and virtual international research center and a place of communication between science, politics and business. IZA is an independent nonprofit organization supported by Deutsche Post Foundation. The center is associated with the University of Bonn and offers a stimulating research environment through its international network, workshops and conferences, data service, project support, research visits and doctoral program. IZA engages in (i) original and internationally competitive research in all fields of labor economics, (ii) development of policy concepts, and (iii) dissemination of research results and concepts to the interested public.
\end{abstract}

IZA Discussion Papers often represent preliminary work and are circulated to encourage discussion. Citation of such a paper should account for its provisional character. A revised version may be available directly from the author. 


\section{ABSTRACT \\ How a Mandatory Activation Program Reduces Unemployment Durations: The Effects of Distance*}

In an experimental setting some Danish unemployed workers were assigned to an activation program while others were not. Unemployed who were assigned to the activation program found a job more quickly. We show that the activation effect increases with the distance between the place of residence of the unemployed worker and the place where the activation took place. We also find that the quality of the post-unemployment jobs was not affected by the activation program. Both findings confirm that activation programs mainly work because they are compulsory and unemployed don't like them.

JEL Classification: C41, H55, J64, J65

Keywords: unemployment insurance, unemployment duration, experiment, activation programs

Corresponding author:

Jan C. van Ours

CentER

PO Box 90153

5000 LE Tilburg

The Netherlands

E-mail: vanours@uvt.nl

\footnotetext{
* Financial support from the Danish Social Science Research Council and the Strategic Program for Welfare Research are gratefully acknowledged. The authors thank the Danish National Labor Market Authority for making their data available.
} 


\section{Introduction}

Labor market programs often combine elements of monitoring and compulsion. The monitoring component makes the unemployed aware of the required search activities in order to remain eligible for unemployed benefits, the compulsion component stimulates unemployed to find a job more quickly because of the increased costs of being unemployed. The empirical effects of monitoring and compulsion are confirmed in the small literature of experimental evaluation studies performed in the U.S. and Europe. Meyer (1995) for example in his overview of unemployment insurance experiments in the U.S. shows that enforcing work search rules and strengthening work tests affect the speed with which people leave unemployment. Klepinger et al. (2002) analyze a 1994 experiment in Maryland in which several treatments are studied simultaneously. It turns out that more intensive search requirements, verification of employer contacts and assignment to a job search workshop reduced unemployment benefit duration. Interestingly, the latter effect occurred because workers left unemployment immediately prior to their scheduled workshop, thus avoiding attendance. Similarly, Black et al. (2003) studying a reemployment service experiment in Kentucky find that the treatment effect is largely accomplished by early exits which coincide in time with the letters sent out to notify the benefit claimants of their obligations. In Europe the findings in experimental evaluation studies are similar. Gorter and Kalb (1996) find that intensive counseling and monitoring of Dutch unemployed reduced their unemployment duration. Dolton and O'Neill $(1996,2002)$ analyzing experiments in the UK, where unemployed were obliged to attend meetings with a counselor find that the interviews reduced the male unemployment rate.

In Graversen and Van Ours (2008a, 2008b) we evaluate a mandatory activation program in Denmark which was implemented in an experimental setting. In two Danish counties about half of the newly unemployed workers were randomly assigned to the program while the other half got a regular treatment. We show that assignment to the treatment group increased the job finding rate of unemployed workers on average with $30 \%$. The main 
effect of the treatment occurs in the range 10-25 weeks of unemployment. As we discuss in more detail later on, because of the experimental set-up it is easy to determine the overall effect of the activation program. The question why the program worked is much harder to address. In our previous studies we concluded that the treatment effect of the activation program is mainly driven by the threat effect at the start of the experiment, the intensive monitoring and counseling in between programs and by the threat of having to enter a training program later on. We concluded that the effectiveness of the activation programs is driven mostly by the compulsory nature. Rosholm (2008) studying the same Danish labor market experiment confirms our findings. He focuses on the threat effect finding that the treatment effect disappears once the estimated risk of participation is included as an explanatory variable in the exit rate out of unemployment.

In the current paper we investigate the activation program in more detail focusing on the heterogeneity of the treatment effect. A possible reason for workers to dislike activation programs is that counseling and program participation are time consuming. There are two possible reasons for this. First, it could be that the program activities themselves are time consuming since workers have to attend them regularly and over long calendar time periods. Second, it could be that the travel related to the program activities is time consuming. We distinguish between the two possible explanations by investigating whether the treatment effect is related to the distance between the municipality of residence and the municipality in which the activation program takes place. Our main finding is that indeed the treatment effect increases with this distance.

The paper is set-up as follows. In the next section we present some theoretical considerations about the way activation programs might affect the behavior of unemployed workers. In section 3 we provide details of the Danish experiment and in section 4 we discuss some stylized findings concerning the intensity of program activities and concerning the relationship between distance and job finding rates. Section 5 presents our empirical analysis of the determinants of the job finding rates and the quality of post- 
unemployment jobs. Section 6 concludes.

\section{Activation and active labor market programs}

To illustrate how an activation program might affect the behavior of individual unemployed workers we use a simplified search model. We distinguish between an activation effect related to compulsory participation and a human capital effect related to the improvement of the labor market position of the individual. The activation effect is considered to be identical to a decrease in the utility of unemployment; the human capital effect is equivalent to an increase of search effectiveness (the probability to get a job offer conditional on a contact). So the activation effect will increase the search intensity while the human capital effect will increase the acceptance probability because it makes the worker more attractive for a potential employer or makes search more efficient, i.e. less costly. The two effects are observationally equivalent but may have different implications.

Workers are assumed to be risk-neutral and cannot save; hence they consume all their income each period. This assumption rules out the possibility that agents save to insure themselves against the loss of income due to unemployment. Once a worker becomes unemployed, he receives an unemployment benefit that is constant over the unemployment spell. For simplicity we assume that labor is homogeneous, i.e. all jobs offer the same wage $w$ net of taxes while unemployed workers receive unemployment benefits $b$, with $b \leq w$ being the replacement rate. Unemployed workers are looking for job offers and as soon as they get one they will accept it. Thus the unemployed have only one instrument of search, their search intensity. An unemployed worker is assumed to search for a job with search intensity $s \geq 0$. The disutility of searching at intensity $s$ equals $\gamma(s)$, such that $\gamma(s)=\frac{1}{2} \gamma s^{2}$, with $\gamma>0$. So the disutility of search increases with the search intensity with an increasing marginal disutility. The search for a job generates a flow of job offers, which follow a Poisson process with arrival rate $\mu s$. The arrival rate of job offers consists of two parts, one part $(\mu)$ is determined by the state of the labor market i.e. the number of vacancies and unemployed and the 
other part $(s)$ is determined by the optimizing behavior of the unemployed worker. To illustrate the activation effect we assume that all unemployed workers have to attend a job search assistance program that lasts from the beginning of the unemployment spell until the worker finds a job. The job search program affects the unemployed worker in two ways. First, the human capital effect increases the effectiveness of search which reduces his search costs with a fraction $\sigma \in(0,1)$. Second, the activation effect, i.e. the job search program reduces the utility derived from the flow of benefits with a fraction $p \in(0,1)$. In other words the activation part of the job search program has the same effect as a penalty on unemployment benefits. Now the following Bellman equation can be derived for the unemployed workers, with $V_{u}$ denoting the expected discounted vale of being unemployed:

$$
\rho V_{u}=\max _{s}\left\{(1-p) b-(1-\sigma) \gamma(s)+\mu s\left(V_{e}-V_{u}\right)\right\}
$$

where $V_{e}$ is the value of being employed and $\rho$ is the discount rate. The flow value of unemployment consists of two parts: the flow of utility during unemployment (utility of benefits minus search costs) and the expected flow of additional income after the job is found. The optimal search intensity $s^{*}$ follows directly from differentiating equation (1) and is given by ( $1-$ $\sigma) \gamma^{\prime}\left(s^{*}\right)=\mu\left(V_{e}-V_{u}\right)$ from which it is easy to derive that

$$
s^{*}=\frac{\mu\left(V_{e}-V_{u}\right)}{(1-\sigma) \gamma}
$$

So, the optimal search intensity increases with the difference between the values of employment and unemployment - and thus with the size of $p$ and with the job search subsidy $\sigma$. Furthermore, optimal search intensity is higher when search costs are lower and when the labor market is tight. For the employed workers the following Bellman equation holds:

$$
\rho V_{e}=w+\delta\left(V_{u}-V_{e}\right)
$$

where $V_{e}$ is the expected discounted value of being employed and $\delta$ is the job separation rate, which is assumed to be exogenous. Equation (3) says that the flow value of being employed for a worker equals the utility from 
the wage he receives each period plus the probability $\delta$ that the match is dissolved, in which case he becomes unemployed and receives $V_{u}$ instead of $V_{e}$.

Using equation (3) we can rewrite the optimal search intensity as

$$
s^{*}=\frac{\mu\left(w-\rho V_{u}\right)}{(1-\sigma) \gamma(\rho+\delta)}
$$

Now defining $s_{a}^{*}$ as the optimal search intensity for the workers in the treated group and $s_{c}^{*}$ as the optimal search intensity for the workers in the control group who are not obliged to participate in the job search program and assuming that for both groups wages, labor market, job destruction rates and the discount rate are identical, while $\sigma_{c}=0$ we find for the treatment effect, i.e. the ratio of the search intensities of both groups:

$$
\frac{s_{a}^{*}}{s_{c}^{*}}=\frac{w-\rho V_{u, a}}{\left(1-\sigma_{t}\right)\left(w-\rho V_{u, c}\right)}
$$

So, the search intensity of unemployed workers in activation programs is higher for two reasons. First, through the human capital effect, the costs of job search are reduced. Second, through the activation effect the value of being unemployed is lower. ${ }^{1}$ Empirically we distinguish between the two explanations by analyzing differences in treatment effects across individuals. In particular we consider the effect of physical distance between the unemployed worker and the activation program. The human capital part of the program is uncorrelated with the travel distance but the compulsion part does vary with the distance. If individuals live further away from the place where activation occurs the perceived costs of participation in the program (travel costs including travel time) are higher. Then the treatment effect should increase with the distance between worker and activation program.

\footnotetext{
${ }^{1}$ Van Ours (2007) provides a more extended model that also accounts for job creation, job destruction, wage bargaining and matching. In this extended model the search subsidy and activation effect also influence wage bargaining through the effect on the value of being unemployed. Note that the effects on wages are opposite. Because the search subsidy increases the value of unemployment wages are expected to be higher; and because the activation effect reduces the value of unemployment wages are expected to be lower.
} 


\section{The Danish experiment}

\subsection{Set-up of the experiment}

To assess the effectiveness of an activation program two Danish counties - Storstrøm County and South Jutland County each with approximately 250,000 inhabitants - participated in a field experiment. In the experiment half of the newly unemployed UI benefit recipients who registered themselves as unemployed at the Public Employment Service (PES) during the period from November 1, 2005 to February 28, 2006, were assigned to an activation program. The individuals constituting the treatment group of the experiment were all born between the $1^{\text {st }}$ and the $15^{\text {th }}$ of a given month. The other half of the newly unemployed UI benefit recipients received the normal services from the PES. These individuals constituting the control group were born on the $16^{\text {th }}$ or a later day of a given month. Since selection into treatment or control group is based on birth dates within a given month and the timing of birth within a particular month is unrelated to job finding rates, the experiment is truly random.

The procedure used for the treatment group was as follows. When an individual notified the PES that he/she was unemployed, within 1.5 weeks the individual received a letter saying that he/she was selected to participate in the program. The letter also gave a short description of the activities contained in the program. After 5-6 weeks of unemployment individuals had to participate in a two-week job search program. After that the individuals had to attend meetings once a week (in Storstrøm) or once every second week (in South Jutland). The purpose of the meetings was to assist individuals in their job search and to monitor their job search efforts. The individuals could also receive job offers mediated by the PES. After 4 months of unemployment individuals had to participate in an activation program with a duration of at least 3 months. Individuals who did not find a job after 6-7 months had to participate in a longer meeting with a case worker and a new job plan was made containing a description of the activities to improve the chances of finding a job. 
The services offered to the control group during the early stage of the unemployment period were much less intensive than the services offered to the treatment group. Individuals in the control group typically would have to participate in an activation program after one year of unemployment. UI benefit recipients below 30 and UI benefit recipients above 60 would have to participate in an activation program after 6 months of unemployment though. Job search assistance and monitoring was less intensive and less formalized for the control group than for the treatment group.

\subsection{Data}

The data used in our analysis come from three different sources. The first data source is the administrative registers of the PES. From these registers we have the following pieces of information for each individual: treatment status (in treatment group or control group), age, sex, immigrant status (immigrant or non-immigrant), country of origin, first week of the individuals unemployment spell (can be one of the weeks from the last week of October (week 43) in 2005 to the last but one week of February (week 8) in 2006, i.e. one of the weeks in the assignment period of the experiment), county where the individual lives, geographic location of the local PES office where the individual has registered as unemployed, and previous occupation. ${ }^{2}$ There is also information about all meetings (type and date) between the unemployed individuals and caseworkers at the PES or with private contractors.

The second data source is the DREAM database developed by the Danish National Labor Market Authority. From the DREAM database we have detailed weekly information about individuals' receipt of different public income transfers and individuals' participation in activation programs. The information in the database is available up to the end of 2007.

The third data source is Statistics Denmark with databases containing information on educational attainment, accumulated work experience, marital status, number and age of children, municipality of residence, start and

\footnotetext{
${ }^{2}$ The occupational classification is based on the name of the UI fund that pays UI benefits to the individual.
} 
end dates of employment periods, and various job characteristics (hourly wage rate, municipality of workplace, level of qualifications needed in job). ${ }^{3}$

We combine the event history information from the different data sources to determine the duration of unemployment spells, the duration of employment spells, and the relevant exit states. We apply the same selection criteria as those used in Graversen and van Ours (2008b). However, since we use an updated version of the DREAM database and since we exclude individuals with missing data on explanatory variables and individuals with missing data on municipality of residence the sample size is slightly smaller in this paper. Our analysis is based on data for 2105 individuals from South Jutland County and 2368 individuals from Storstrøm County.

\subsection{Distances}

There are 4 local PES offices in each of the counties involved in the experiment. The PES offices in South Jutland County are located in Haderslev, Sønderborg, Åbenrå and Tønder and the PES offices in Storstrøm County are located in Næstved, Vordingborg, Nykøbing Falster and Nakskov. Figure 1a illustrates the geographical location of the PES offices. Thin lines are municipal boundaries and municipalities within South Jutland County and Storstrøm County are marked with various grey shading.

Individuals have a choice as to which PES office they prefer to go to when they register as unemployed. However, most individuals choose to register with the nearest PES office. Generally, almost all individuals from a given municipality register with the same PES office. ${ }^{4}$

\footnotetext{
${ }^{3}$ The information on start and end dates of employment periods is generally of a lower quality than the information on start and end dates of periods in which public income transfers are received. The algorithm that determines the duration of unemployment and employment periods therefore places more weight on the latter type of information. There is no information in the data about self-employment and the information about employment periods and job characteristics is only available up to the end of 2006. An unemployment spell continues until the individual stopped receiving UI benefits for four consecutive weeks. An employment spell is assumed to continue as long as the individual receives no public income transfers.

${ }^{4}$ There are a few municipalities where the unemployed register with two different PES
} 
Figure 1a illustrates with different grey shading which PES office the majority of the individuals from each municipality went to when registering as unemployed. For example, in the municipalities in South Jutland marked with the lightest grey shading, the largest fraction of individuals registered as unemployed with the PES office in Åbenrå. In the empirical analysis, we assume that all individuals in a given municipality register with the most important PES office, i.e. the office that most individuals go to. ${ }^{5}$

The mandatory activities for the treatment group were not only handled by caseworkers at the PES offices. In both counties private agencies were responsible for the two-week job search programs scheduled after 5-6 weeks of unemployment. The intensive sequence of meetings after the job search program was also contracted out to private agencies for all individuals in the treatment group in South Jutland and for individuals older than 50 in the treatment group in Storstrøm. The offices of the private agencies responsible for the job search programs are located in the same municipalities as the PES offices and the workers have to attend a job search program in the municipality where the PES office with which they registered as unemployed is located. However, to reduce the overall costs of the experiment, the offices because the distance to the two offices is almost the same. In Tinglev for example, $82 \%$ of the unemployed registered with the PES office in Åbenrå and $18 \%$ registered with the PES office in Tønder. In Maribo and Holeby the majority (almost 90\%) of the unemployed registered with the PES office in Nakskov while the rest registered with the PES office in Nykøbing Falster. In all other municipalities more than $90 \%$ of the unemployed registered with one specific PES office.

${ }^{5}$ We do not use information about the actual PES office affiliation. This choice is not essential for a number of reasons. First, only few individuals chose to register with an alternative PES office, i.e. another PES office than the most usual one. Second, the organization of the mandatory activities are very similar across PES offices within a given county (e.g., the meeting intensities and the activation program participation rates are very similar across PES offices). Therefore individuals should not choose a particular PES office because the activities are of a higher quality or because the activities are less time consuming. Third, the distance to the nearest PES office (which is a key figure in our empirical analyses) is not much different between individuals living in the same municipality even if some individuals have a shorter distance to another PES office than the most important one. 
workers who registered with the PES office in Tønder had to go to Åbenrå to participate in the job search program. Figure $1 \mathrm{~b}$ illustrates the distances between each municipality and the job search programs using the intervals $0-4 \mathrm{~km}, 5-24 \mathrm{~km}$ and $25+\mathrm{km}{ }^{6}$

For most of the workers who had to attend meetings with private agencies the offices where meetings were held were located in the same municipality as the PES office with which they registered as unemployed. However, in South Jutland higher educated workers (i.e. workers with a long further or higher education) who registered as unemployed in Tønder or Haderslev had to go to Åbenrå to attend the meetings. Figure 1c illustrates the distances between each municipality in South Jutland County and the offices where meetings are held separately for workers with and without a long further or higher education. ${ }^{7}$

In Storstrøm the private agencies responsible for meetings with workers older than 50 had offices in 8 different municipalities. There were offices in each of the municipalities where the PES offices are located and in four other municipalities (Maribo, Sakskøbing, Fakse and Præst $\varnothing$ ). The workers would generally have to go to the nearest office to attend the meetings. Figure $1 \mathrm{~d}$ illustrates the distances between each municipality in Storstrøm County and the offices where meetings are held separately for workers younger and older than 50 .

In the empirical analyses we generally use the distance to the job search program as our distance measure. However, when analyzing job finding rates in section 5.1 we let distance be a time-varying variables. Before and during the job search program distances are set equal to the distances to the job search programs. After the job search program distances are set equal to distances to the offices where meetings take place. ${ }^{8}$

\footnotetext{
${ }^{6}$ For each municipality the distance is calculated as the distance between the largest city in the municipality and the city where the office responsible for the job search program is located. Distances are based on road distances using the quickest routes suggested by Michelin Route Planner.

${ }^{7}$ Distances to meetings are calculated in the same way as distances to job search programs.

${ }^{8}$ We have no knowledge of the distances to the training programs scheduled after 4
} 


\section{Treatment effects - stylized facts}

We do the empirical analysis separately for the two counties because the organization of the re-employment activities offered to the unemployed differs considerably between counties. Table 1 shows the meeting intensity, the job search program participation rate and the training program participation rate in the two regions.

In the treatment group the average weekly meeting intensity during the first 10 weeks of unemployment is about twice as large in Storstrøm as in South Jutland. The meeting intensity is also somewhat higher in Storstrøm than in South Jutland during weeks 11-20. The higher meeting intensity in Storstrøm, of course, has to do with the design of the experiment. In Storstrøm unemployed workers in the treatment group were supposed to have meetings every week in the period between the job search program and the training program whereas in South Jutland the intended meeting frequency was once every second week.

The job search program participation rate is also considerably higher in Storstrøm than in South Jutland in weeks 1-10, and whereas a significant fraction of the control group in Storstrøm participates in job search programs almost none of the individuals in the control group in South Jutland participates in this type of program. The treatment group has to participate in training programs after approximately four months of unemployment. The treatment groups' participation rate in such programs is somewhat higher in Storstrøm than in South Jutland during weeks 11-20 and 21-30. In sum, during the first 20 weeks of unemployment the additional mandatory activities imposed on the treatment group (defined as the difference between the activity level of the treatment group and the control group) is most comprehensive in Storstrøm. ${ }^{9}$

months of unemployment. The training programs may in principle take place anywhere but the supply of training program slots is generally largest in the larger cities where there are more educational institutions and work places to choose from.

${ }^{9}$ A more detailed description of the county differences in the implementation of the experiment and in the organization of the mandatory re-employment activities is given in Graversen et al. (2007) and Rosholm (2008). 
Table 1 also presents meeting intensities and program participation rates separately for the three distance categories. There is a tendency, most pronounced in Storstrøm, that meeting intensities and program participation rates fall with distance to the nearest PES office. However, this tendency exists for both the treatment group and the control group. Therefore, the difference between the activity level of the treatment group and the control group does not vary with distance.

Figure 2 illustrates the county specific survivor functions separately for the treatment group and the control group. As shown the treatment group leaves unemployment more quickly than the control group in both counties. The treatment effect (measured as the difference between the survivor functions of the control group and the treatment group) occurs earlier in Storstrøm than in South Jutland, but otherwise the effect evolves in almost the same way over time. In both counties the treatment effect peaks at 7-9 percentage points in the range 10-25 weeks after the first day of unemployment.

To get a first impression of the importance of the distance to the mandatory re-employment activities that individuals in the treatment group have to attend, we calculated the differences between the survivor functions of the control group and the treatment group splitting up the sample according to distance. Figure 3 shows that indeed distance seems to matter. Generally, the treatment effect is largest for individuals living more than 25 kilometers away from a PES office. Table 2 mimics the graphical results in Figure 3. After 10, 15, 20, 25 and 30 weeks the effect is largest for the distance category $25+\mathrm{km}$. The presence of a larger effect for individuals living far away from a PES office is particularly noticeable in Storstrøm. For example, while the effect after 15 weeks is 19 percentage points for the distance category $25+\mathrm{km}$ the effect is only 5 percentage points for the distance categories 0-4 $\mathrm{km}$ and 5-24 km. Hence, while the overall treatment effect of the intensive mandatory activation program does not differ much between counties, the relationship between distance to re-employment activities and the treatment 
effect of the activities seems to be somewhat different in the two counties. ${ }^{10}$

\section{Empirical analysis}

\subsection{Job finding rates}

To investigate the interaction between treatment effect and distance in more detail we analyze job finding rates, which are defined as transitions out of the benefit system. The individual job finding rate is assumed to have a mixed proportional hazard $(\mathrm{MPH})$ specification. The job finding rate at unemployment duration $t$ conditional on observed characteristics $x$, unobserved characteristics $v$ and treatment status $P$ is specified as

$$
\theta(t \mid x, P, v)=\exp \left(x^{\prime} \beta+\varphi(t)+\zeta_{0} P+\zeta_{1} P . d_{5-24}+\zeta_{2} P . d_{25+}+v\right)
$$

where $x$ is a vector of personal characteristics, $P$ is a dummy variable representing whether $(P=1)$ or not $(P=0)$ the individual was assigned to the treatment group, the d's are two dummy variables indicating whether the distance between the municipality of the worker and the nearest activation program is 5 -24 kilometers or $25+$ kilometers. ${ }^{11}$ Furthermore, $\beta$ is a vector of parameters representing the effect of personal characteristics. The $\zeta$ 's are the parameters of main interest. First, $\zeta_{0}$ indicates whether or not there is a treatment effect for individuals who live close by their PES. Second, $\zeta_{1}$ and $\zeta_{2}$ indicate whether the treatment effect is different if the distance to the nearest PES is larger. In the baseline model we assume that the $\zeta \mathrm{s}$ are independent of the duration of unemployment and identical for different groups of workers.

The function $\varphi(t)$ represents duration dependence in the transition rates

$$
\varphi(t)=\Sigma_{k} \mu_{k} I_{k}(t)
$$

\footnotetext{
${ }^{10}$ The larger distance effect in Storstrøm may have to do with the higher activity level in first months of the unemployment spell if individuals dislike the activities/travelling and they form their expectations about future participation in mandatory activities on the basis of the level of activities in the (near) past.

${ }^{11}$ As discussed before for some individuals these dummy variables are time-varying.
} 
where the $\mu$-parameters describe the stepwise duration dependence with $k$ $(=1, . ., 41)$ as a subscript for weekly duration intervals up to 30 weeks and broader intervals from then onwards, and we normalize $\mu_{1}=0 .{ }^{12}$

Finally, the unobserved heterogeneity is assumed to follow a discrete distribution with two points of support $v^{a}$ and $v^{b}$, with $\operatorname{Pr}\left(v=v^{a}\right)=p$ and $\operatorname{Pr}\left(v=v^{b}\right)=1-p$ and $p$ has a logit specification. The two points of support represent random effects assumed to be orthogonal to the observed characteristics of the individuals.

The parameters are estimated using the method of maximum likelihood. The relevant parameter estimates are shown in Table 3; the upper part shows the results for South Jutland, the lower part is for Storstrøm. ${ }^{13}$ Part $a$ reports the average treatment effect per county. This average treatment effect is approximately the same for both counties; the average exit rate from unemployment is about $26-27 \%$ higher for individuals in the treatment group.

In part $b$ of Table 3 we distinguish the treatment effect by distance. In South Jutland the treatment effect increases with distance, but the treatment effects for the shorter distances are estimated imprecisely. The additional treatment effect for individuals who live more than $25 \mathrm{~km}$ from their activation program is significantly different from zero. For Storstrøm there is a clear treatment effect for individuals who live close to the treatment program, while there is no additional treatment effect for individuals who live further away from their treatment program.

The distribution of personal characteristics in the treatment group and the control group is very much the same, as was to be expected from a random assignment of individuals to treatment and control group. However, as shown in the appendix, there seems to be a correlation between age and distance. Younger people live closer to the activation programs. This may be a big city effect - more older workers live in rural areas where

\footnotetext{
${ }^{12}$ The broader intervals are 5 weekly intervals up to 80 weeks, and the interval $80+$ weeks.

${ }^{13}$ In the tables we only report the treatment effects; the full estimation results are available on request.
} 
they are more distant from treatment programs. Because of the correlation between distance and age there is the danger of the distance effects being contaminated by age differences. Therefore, part $c$ provides treatment effects by age group. As shown there are differences in treatment effect by age group. In particular for workers older than 40 in South-Jutland and workers older than 50 in Storstrøm there is no interaction between distance and treatment effect. As discussed before workers older than 50 where treated differently in Storstrøm, which reduced the variation in distance for this group of workers. Therefore when studying the interaction between duration of unemployment, distance and treatment effect we removed the workers over age 50 from the sample. Then, as shown in part $d$ of Table 3 now the two counties are more alike in terms of the interaction between distance and treatment effects. For workers below age 50 we only find a significant treatment effect if they live more than $25 \mathrm{~km}$ away from the place where the activation takes place. As shown in part $e$ there are also clear interactions between unemployment duration and the treatment effects. The treatment effects are largest when the distance to the treatment program is more than 25 kilometers and the duration of unemployment is more than 10 weeks.

Table 4 shows a sensitivity analysis for workers below age 50 when we use $25 \mathrm{~km}$ as a threshold. For South Jutland there is no treatment effect for unemployed who live close to the activation program, but there is a significant treatment effect for those that live further away than $25 \mathrm{~km}$. Part $c$ of Table 4 shows that there is also an interaction between unemployment duration and distance; the treatment effect is strongest for unemployment durations longer than 10 weeks for unemployed who live further away than $25 \mathrm{~km}$. For Storstrøm for workers who live less than $25 \mathrm{~km}$ from the activation program there is a positive and significant treatment effect, but for workers who live further away than $25 \mathrm{~km}$ there is an additional positive and significant treatment effect. As shown in part $c$ also for Storstrøm there is an interaction between unemployment duration and distance. The largest treatment effect are for unemployed who with an unemployment spell of more than 10 weeks who live far from the activation program. 


\subsection{Post-unemployment jobs}

An important issue in the debate on the effectiveness of labor market programs is whether they affect the quality of the post-unemployment jobs. Figure 4 shows how long post-unemployment employment spells lasted. Clearly, there are many workers who loose their post-unemployment job rather quickly, but there doesn't seem to be a difference between individuals from the treatment group and individuals from the control group. Table 5 shows that the post-unemployment jobs of individuals in the control group are very similar to those in the treatment group. Neither in terms of hourly wages, finding a job in the municipality of residence, absence from work or qualifications needed there is a clear relationship with the distance between the municipality of residence and the activation program.

In order to investigate whether indeed there are no differences in postunemployment job quality we performed a more detailed statistical analysis. We estimated log wage equations with the same explanatory variables as in the job finding rates including a dummy indicator for being member of the treatment group. ${ }^{14}$ As shown in the upper part of Table 6 there is a negative but insignificant treatment effect on wages in South Jutland, which doesn't vary with the distance. Whereas unemployed in South Jutland found a job more quickly when they lived further away than $25 \mathrm{~km}$ from the activation program, the quality of the job in terms of wages is not affected by this distance. The same holds for Storstrøm.

We also investigated whether the job separation rate depends on the distance between worker and activation program. In the same way as we specified a MPH model for the job finding rate we also specified a MPH model for the job separation rate with unobserved heterogeneity following a discrete distribution with two points of support. We allowed for correla-

\footnotetext{
${ }^{14}$ There are also many workers for which the wage information is not available. We investigated the relevance of potential selectivity in the observed wages by including a Heckman selection term in the wage regressions. The probit model of presence of information underlying the selection term included occupational dummies which were excluded from the wage equation. However, we did not find selectivity to be issue; therefore we report parameter estimates without correcting for selectivity.
} 
tion between the unobserved heterogeneity in the job finding rate and the job separation rate to account for potential selectivity in the job separation rate. As shown in Table 6 the job separation rate of unemployed in the treatment group is not significantly different from the job separation rate of unemployed workers in the control group. Also, the treatment effect in the job separation rate does not vary with the distance between unemployed and activation program. All in all, there is indeed no relationship between the distance and the quality of post-unemployment jobs. Even though unemployed workers who live far from the place where the activation program is administered find a job more quickly this is not at the expense of the quality of the job. ${ }^{15}$

\section{Conclusions}

In an experimental setting some Danish unemployed workers were assigned to an activation program while others were not. Unemployed who were assigned to the activation program found a job more quickly. We find no evidence of the quality of post-unemployment jobs being affected by the activation. From a post-unemployment perspective activation is neither harmful nor beneficial for a worker. We also investigated why activation works. In theory there are two effects. The activation effect related to the mandatory program participation reduces the value of being unemployed thereby increasing the search intensity. The human capital effect improves the labor market position of the individual thereby increasing the effectiveness of search. Empirically we distinguish between the two explanations by analyzing differences in treatment effects across individuals. In particular we consider the effect of physical distance between the unemployed worker and the activation program. The human capital part of the program is uncorrelated with the travel distance but the compulsion part increases with the distance. If individuals live further away from the place where activation

\footnotetext{
${ }^{15}$ This finding is not unusual as for example both Black et al. (2003) and Klepinger et al. (2002) find no evidence of the post-unemployment earnings of workers exposed to compulsory programs being affected.
} 
occurs the perceived costs of participation in the program are likely to be higher. We find that the activation program increases the job finding rate. And, indeed we find that unemployed living further away from their activation program find a job more quickly. Clearly the compulsion effect must be responsible for this. Activation programs mainly work because they are compulsory and unemployed don't like them. 


\section{References}

[1] Black, D.A., Smith, J.A., Berger, M.C., Noel, B.J. (2003) Is the threat of reemployment services more effective than the services themselves? Evidence from random assignment in the UI system, American Economic Review, 93, 1313-1327.

[2] Dolton, P., O'Neill, D. (1996) Unemployment duration and the Restart effect: some experimental evidence. Economic Journal, 106, 387-400.

[3] Dolton, P., O'Neill, D. (2002) The long-run effects of unemployment monitoring and work-search programs: experimental evidence from the United Kingdom, Journal of Labor Economics, 20, 381-403.

[4] Gorter, C., Kalb, G.R.J. (1996) Estimating the effect of counseling and monitoring the unemployed using a job search model, Journal of Human Resources, 31, 590-610.

[5] Graversen, B.K., Damgaard, B., Roshdahl, A.(2007) Hurtigt i gang; evaluering af et forsøg med en tidlig og intensiv beskæftigelsesindats for forsikrede ledige ("Quick Start: evaluation of an experiment with early and intensive re-employment services for unemployment insurance claimants") Report 07-10, Danish National Centre for Social Research, Copenhagen.

[6] Graversen, B.K., Van Ours, J.C. (2008a) Activating unemployed workers works; experimental evidence from Denmark. Economics Letters, 100, 308-310.

[7] Graversen, B.K., Van Ours, J.C. (2008b) How to help unemployed find jobs quickly; experimental evidence from a mandatory activation program, Journal of Public Economics, 92, 684-695.

[8] Klepinger, D.H., Johnson, T.R., Joesch, J.M. (2002) Effects of unemployment insurance work-search requirements: the Maryland experiment, Industrial and Labor Relations Review, 56, 3-22. 
[9] Meyer, B.D. (1995) Lessons from the U.S. unemployment insurance experiments, Journal of Economic Literature, 33, 91-131.

[10] Rosholm, M. (2008) Experimental evidence on the nature of the Danish employment miracle, IZA Discussion Paper no. 3620.

[11] Van Ours, J.C. (2006) Compulsion in active labor market programmes, National Institute Economic Review, 202, 67-78. 


\section{A Appendix: Definitions and means of explanatory variables}

The explanatory variables used in the analysis are defined as follows:

- Male: dummy variable - reference group: female

- Dummies for age: 30-39, 40-49, 50+ years - reference group: Age < 30 years.

- Dummies for occupation: 1: Academics, engineers, economists; 2: Officials, servants and salaried employees - white collar; 3: Construction; 4: Trade; 5: Self-employed; 6: Multidisciplinary; 7: Welfare workers; 8: Metal workers; 9: Food industries; 10: Other industries - reference group: Unskilled and skilled workers - blue collar.

- Dummies immigrant status: Western, non-western - reference group: native Danes.

- Previous unemployment status: Continuous variables indicating the time period on public income support (0-1); Previous unemployed 1: 0-1 year before unemployment spell, Previous unemployed 2: 1-2 years before unemployment spell, Previous unemployed 3: 2-3 years before unemployment spell

- Excluded Member: dummy variable for members of treatment group, that do not participate; many of these individuals became unemployed because of bad weather and they will return to their job quickly once the weather improves - reference group: members of treatment group that participate.

- Dummies for experience: 5-10, 10-15, 15-20, 20+ years, reference group: 0-5 years.

- Dummies for family status: Married, cohabiting, reference group: single.

- Children: dummy variable for the presence of children 
- Dummies for educational attainment: No educational information, upper secondary school, vocational education, short further education, long further education, higher education.

Table 7 gives an overview of the means of the explanatory variables distinguished by county and distance category.

\section{B Tables and graphs}


Tab. 1: Weekly meeting intensities, job search program participation and training program participation by weeks of unemployment (1-10, 11-20, 21-30) and distance in kilometers $(0-4,5-24,25+)$

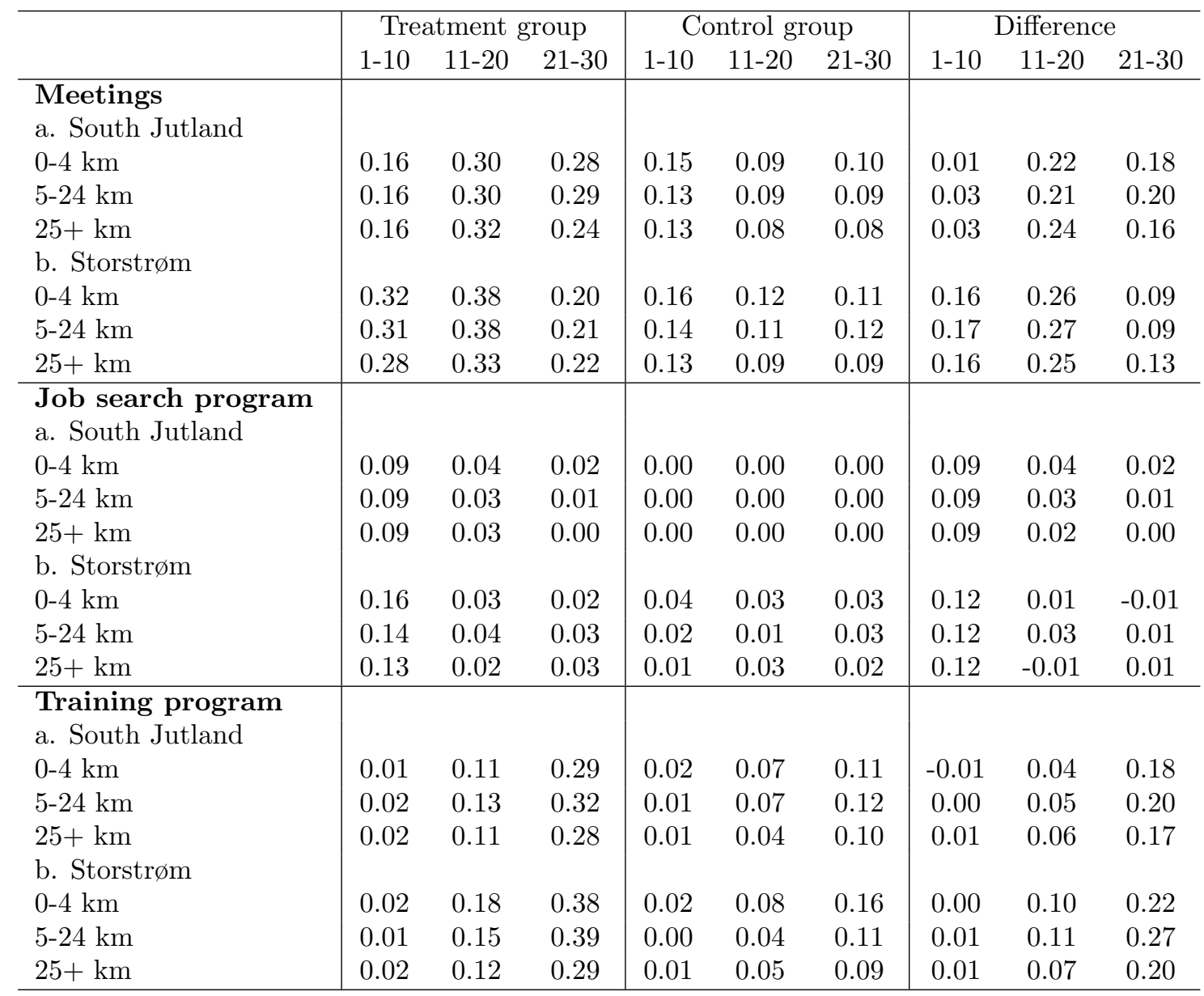

Note: Meeting intensity $=$ the number of meetings in a given week divided by the number of individuals who are still unemployed in this week; program participation rate $=$ the number of individuals who participate in a program in a given week divided by the number of individuals who are still unemployed in this week. 
Tab. 2: Differences between survival functions treatment and control group; by weeks after assignment

\begin{tabular}{l|llllll}
\hline Weeks & 5 & 10 & 15 & 20 & 25 & 30 \\
\hline South Jutland & & & & & & \\
$0-4 \mathrm{~km}$ & 2.4 & $2.9^{* *}$ & $7.7^{* *}$ & $8.8^{* *}$ & 4.6 & 2.2 \\
$5-24 \mathrm{~km}$ & 0.3 & $7.6^{* *}$ & $6.6^{*}$ & $4.8^{* *}$ & $7.3^{* *}$ & $6.4^{* *}$ \\
$25+\mathrm{km}$ & 0.9 & $9.9^{* *}$ & $10.7^{* *}$ & $12.1^{* *}$ & $9.3^{* *}$ & $8.0^{* *}$ \\
Total & 1.1 & $6.9^{* *}$ & $8.3^{* *}$ & $8.5^{* *}$ & $7.1^{* *}$ & $5.6^{* *}$ \\
\hline Storstrøm & & & & & & \\
$0-4 \mathrm{~km}$ & 4.3 & $6.8^{* *}$ & 5.1 & $7.3^{* *}$ & $7.4^{* *}$ & $7.1^{* *}$ \\
$5-24 \mathrm{~km}$ & 0.4 & $4.9^{* *}$ & $4.6^{*}$ & $4.8^{*}$ & $5.7^{* *}$ & 2.6 \\
$25+\mathrm{km}$ & $7.7^{* *}$ & $9.6^{* *}$ & $18.7^{* *}$ & $22.3^{* *}$ & $15.9^{* *}$ & $14.2^{* *}$ \\
Total & $3.3^{*}$ & $6.5^{* *}$ & $7.4^{* *}$ & $8.9^{* *}$ & $8.2^{* *}$ & $6.1^{* *}$ \\
\hline
\end{tabular}

Note: numbers with a ${ }^{* *}(*)$ are significantly different from zero at a $5 \%(10 \%)$ level. 
Tab. 3: Parameter estimates hazard rate models

\begin{tabular}{|c|c|c|c|c|c|}
\hline & Treatment effect & $\begin{array}{l}\text { Treatment } \\
*(5-24 \mathrm{~km})\end{array}$ & $\begin{array}{l}\text { Treatment } \\
*(25+\mathrm{km})\end{array}$ & -Logl. & $\mathrm{N}$ \\
\hline $\begin{array}{l}\text { South Jutland - all age groups } \\
\text { a. One effect }\end{array}$ & $0.23(0.06) * *$ & - & - & 7510.9 & 2105 \\
\hline $\begin{array}{l}\text { b. By distance } \\
\text { c. By age and distance }\end{array}$ & $0.07(0.11)$ & $0.18(0.15)$ & $0.32(0.15) * *$ & 7508.4 & 2105 \\
\hline Age $<30$ & $-0.07(0.17)$ & $0.19(0.23)$ & $0.41(0.23) *$ & 7504.2 & 2105 \\
\hline Age $30-39$ & $0.11(0.18)$ & $0.28(0.23)$ & $0.48(0.23) * *$ & & \\
\hline Age $40-49$ & $0.03(0.17)$ & $0.04(0.22)$ & $0.10(0.22)$ & & \\
\hline Age $50+$ & $0.31(0.23)$ & $0.12(0.26)$ & $0.18(0.27)$ & & \\
\hline $\begin{array}{l}\text { South Jutland - age }<50 \\
\text { d. By distance } \\
\text { e. By duration and distance }\end{array}$ & $0.01(0.12)$ & $0.16(0.16)$ & $0.35(0.16)^{* *}$ & 5680.0 & 1600 \\
\hline $1-10$ weeks & $0.12(0.15)$ & $0.03(0.19)$ & $0.22(0.19)$ & 5673.6 & 1600 \\
\hline 11-20 weeks & $0.16(0.18)$ & $0.02(0.23)$ & $0.42(0.24) *$ & & \\
\hline $21+$ weeks & $-0.49(0.20) * *$ & $0.73(0.27) * *$ & $0.79(0.31) * *$ & & \\
\hline $\begin{array}{l}\text { Storstrøm - all age groups } \\
\text { a. One effect }\end{array}$ & $0.24(0.05) * *$ & - & - & 8341.1 & 2368 \\
\hline $\begin{array}{l}\text { b. By distance } \\
\text { c. By age and distance }\end{array}$ & $0.25(0.08) * *$ & $-0.12(0.11)$ & $0.19(0.14)$ & 8338.8 & 2368 \\
\hline Age $<30$ & $0.48(0.15) * *$ & $-0.34(0.19) *$ & $-0.17(0.26)$ & 8331.0 & 2368 \\
\hline Age $30-39$ & $-0.01(0.14)$ & $-0.07(0.19)$ & $0.70(0.26) * *$ & & \\
\hline Age $40-49$ & $0.09(0.15)$ & $-0.14(0.18)$ & $0.41(0.23) *$ & & \\
\hline Age $50+$ & $0.41(0.14)^{* *}$ & $-0.13(0.17)$ & $0.09(0.22)$ & & \\
\hline $\begin{array}{l}\text { Storstrøm - age }<50 \\
\text { d. By distance } \\
\text { e. By duration and distance }\end{array}$ & $0.13(0.10)$ & $0.03(0.14)$ & $0.46(0.18)^{* *}$ & 5963.4 & 1702 \\
\hline $1-10$ weeks & $0.13(0.11)$ & $-0.01(0.16)$ & $0.27(0.21)$ & 5958.0 & 1702 \\
\hline 11-20 weeks & $0.19(0.15)$ & $0.13(0.20)$ & $0.89(0.25) * *$ & & \\
\hline $21+$ weeks & $0.01(0.19)$ & $0.12(0.26)$ & $0.99(0.38) * *$ & & \\
\hline
\end{tabular}

Note: All estimates contain covariates for distance, gender, educational attainment, experience, presence of children, dummy variables for the week of inflow, etcetera; standard errors in parentheses; a ** $\left(^{*}\right)$ indicates significance at a $95 \%(90 \%)$ level. 
Tab. 4: Parameter estimates hazard rate models; workers below age 50

\begin{tabular}{l|ccc}
\hline & Treatment effect & $\begin{array}{c}\text { Treatment } \\
*(25+\mathrm{km})\end{array}$ & -Loglikelihood \\
\hline South Jutland & $0.17(0.07)^{* *}$ & - & 5682.4 \\
a. One effect & $0.09(0.08)$ & $0.26(0.14)^{*}$ & 5680.5 \\
b. By distance & & \\
c. By duration and distance & $0.14(0.10)$ & $0.20(0.16)$ & 5677.9 \\
1-10 weeks & $0.16(0.13)$ & $0.40(0.21)^{*}$ & \\
$11-20$ weeks & $-0.15(0.16)$ & $0.42(0.28)^{*}$ & \\
$21+$ weeks & & \\
\hline Storstrøm & $0.21(0.07)^{* *}$ & - & 5966.7 \\
a. One effect & $0.14(0.07)^{* *}$ & $0.45(0.17)^{* *}$ & 5963.4 \\
b. By distance & & \\
c. By duration and distance & $0.12(0.08)$ & $0.27(0.19)$ & 5958.2 \\
1-11 weeks & $0.25(0.12)^{* *}$ & $0.82(0.23)^{* *}$ & \\
$11-20$ weeks & $0.06(0.15)$ & $0.92(0.36)^{* *}$ & \\
$21+$ weeks &
\end{tabular}

Note: Based on 1600 (1702) workers for South Jutland (Storstrøm); all estimates contain covariates for distance, gender, educational attainment, experience, presence of children, dummy variables for the week of inflow, etcetera; standard errors in parentheses; a ${ }^{* *}(*)$ indicates significance at a $95 \%(90 \%)$ level. 
Tab. 5: Characteristics post-unemployment jobs by group of workers and distance to the nearest PES; workers below age 50

\begin{tabular}{|c|c|c|c|c|c|c|c|c|c|}
\hline \multirow[b]{2}{*}{ Distance (kilometers) } & \multicolumn{3}{|c|}{ Treatment group } & \multicolumn{3}{|c|}{ Control group } & \multicolumn{3}{|c|}{ Difference } \\
\hline & $0-4$ & $5-24$ & $25+$ & $0-4$ & $5-24$ & $25+$ & $0-4$ & $5-24$ & $25+$ \\
\hline South Jutland & & & & & & & & & \\
\hline Hourly wage (pre-unempl.) & 130.4 & 127.7 & 128.4 & 123.2 & 132.1 & 127.7 & 7.2 & -4.4 & 0.8 \\
\hline Hourly wage (post-unempl.) & 132.4 & 130.0 & 126.3 & 130.0 & 128.5 & 129.5 & 2.4 & 1.4 & -3.2 \\
\hline$\%$ working in municipality of residence & 37.9 & 17.8 & 30.6 & 39.3 & 19.4 & 33.9 & -1.5 & -1.6 & -3.3 \\
\hline Absence from work (\% of total wage hours) & 3.6 & 4.1 & 3.7 & 3.1 & 3.5 & 4.3 & 0.5 & 0.5 & -0.6 \\
\hline Medium or high qualifications needed & 18.5 & 15.2 & 14.3 & 21.3 & 10.6 & 15.6 & -2.8 & 4.7 & -1.3 \\
\hline Storstrøm & & & & & & & & & \\
\hline Hourly wage (pre-unempl.) & 134.9 & 134.7 & 131.8 & 135.2 & 136.3 & 130.4 & -0.4 & -1.7 & 1.4 \\
\hline Hourly wage (post-unempl.) & 139.6 & 137.2 & 133.6 & 141.7 & 140.4 & 131.3 & -2.1 & -3.2 & 2.2 \\
\hline$\%$ working in municipality of residence & 33.7 & 15.8 & 31.9 & 30.8 & 18.2 & 42.9 & 2.9 & -2.4 & -10.9 \\
\hline Absence from work (\% of total wage hours) & 3.8 & 3.0 & 3.2 & 3.9 & 3.7 & 3.7 & -0.1 & -0.6 & -0.4 \\
\hline Medium or high qualifications needed & 25.3 & 9.7 & 10.4 & 23.0 & 17.7 & 13.7 & 2.3 & -8.0 & -3.3 \\
\hline
\end{tabular}

Note: Wage rates in 2006 Danish Kroner 
Tab. 6: Parameter estimates quality of post-unemployment jobs; workers below age 50

\begin{tabular}{l|ccc}
\hline & Treatment effect & $\begin{array}{c}\text { Treatment } \\
*(25+\mathrm{km})\end{array}$ & -Loglikelihood \\
\hline $\begin{array}{l}\text { South Jutland } \\
\text { Wages }\end{array}$ & & & \\
$\begin{array}{l}\text { a. One effect } \\
\text { b. By distance }\end{array}$ & $-0.02(0.02)$ & & - \\
Employment duration & $-0.01(0.02)$ & $-0.03(0.03)$ & - \\
$\begin{array}{l}\text { c. One effect } \\
\text { d. By distance }\end{array}$ & $0.06(0.08)$ & & 9932.1 \\
\hline Storstrøm & $0.15(0.10)$ & $-0.26(0.17)$ & 9930.5 \\
Wages & & & \\
a. One effect & $-0.01(0.02)$ & & - \\
b. By distance & $-0.01(0.02)$ & $0.03(0.04)$ & - \\
$\begin{array}{l}\text { Employment duration } \\
\text { c. One effect }\end{array}$ & $-0.06(0.08)$ & & 10350.4 \\
d. By distance & $0.09(0.09)$ & $-0.16(0.23)$ & 10350.1 \\
\hline \hline
\end{tabular}

Note: Based on 1600 observations on employment durations (829 on wages) for South Jutland and 1702 observations on employment durations (850 on wages) for Storstrøm; all estimates contain covariates for distance, gender, educational attainment, experience, presence of children, dummy variables for the week of inflow, etcetera; standard errors in parentheses; a ${ }^{* *}(*)$ indicates significance at a $95 \%$ (90\%) level. 
Fig. 1: Public Employment Services - districts a. PES districts

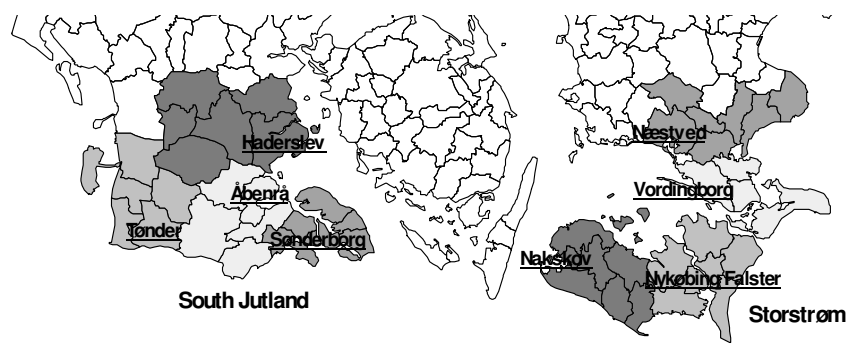

b. Distances to job search programs

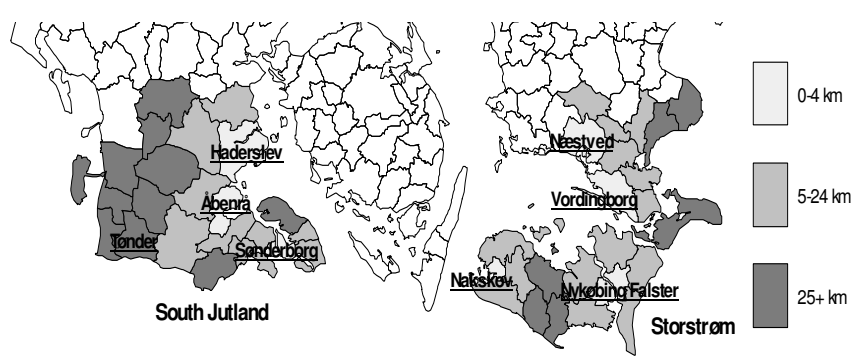

c. Distances to meetings - South Jutland

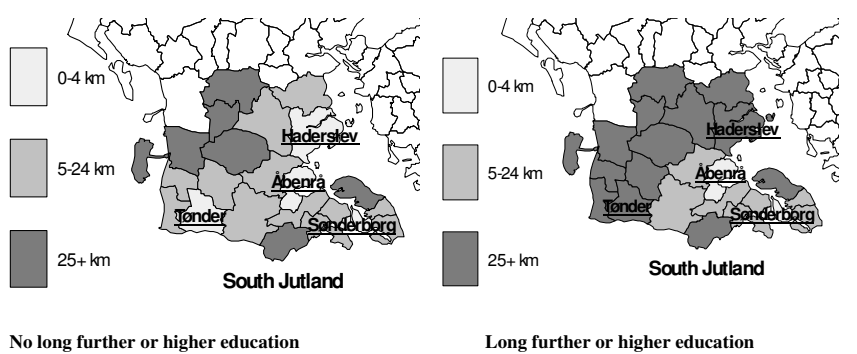

d. Distances to meetings - Storstrøm
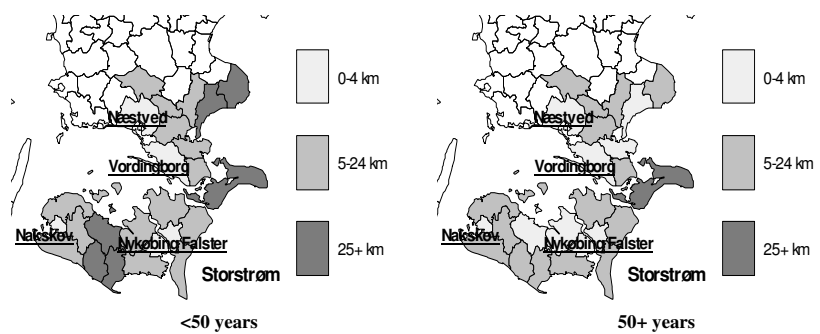
Fig. 2: Fraction of individuals who remain unemployed a. South Jutland

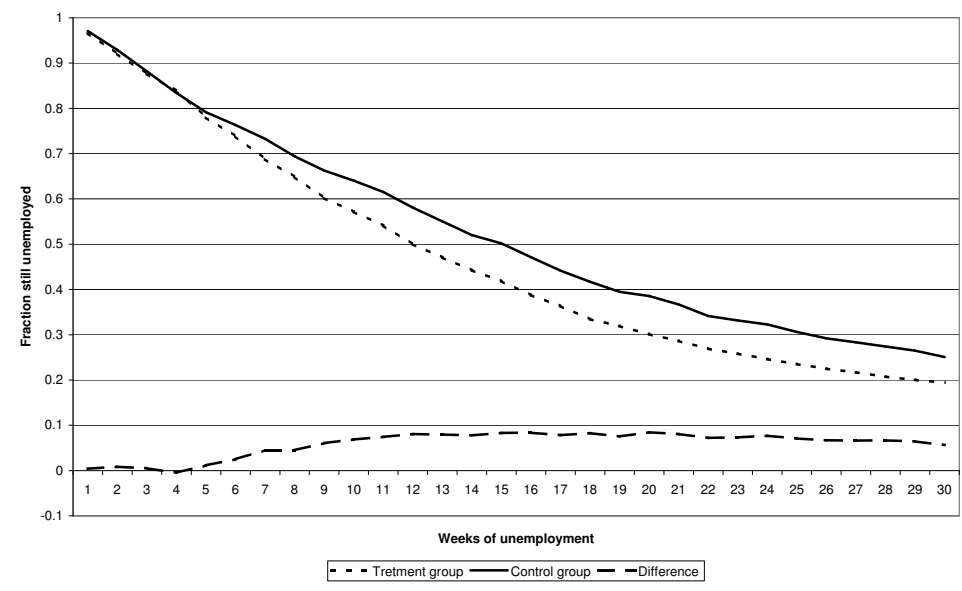

b. Storstrøm

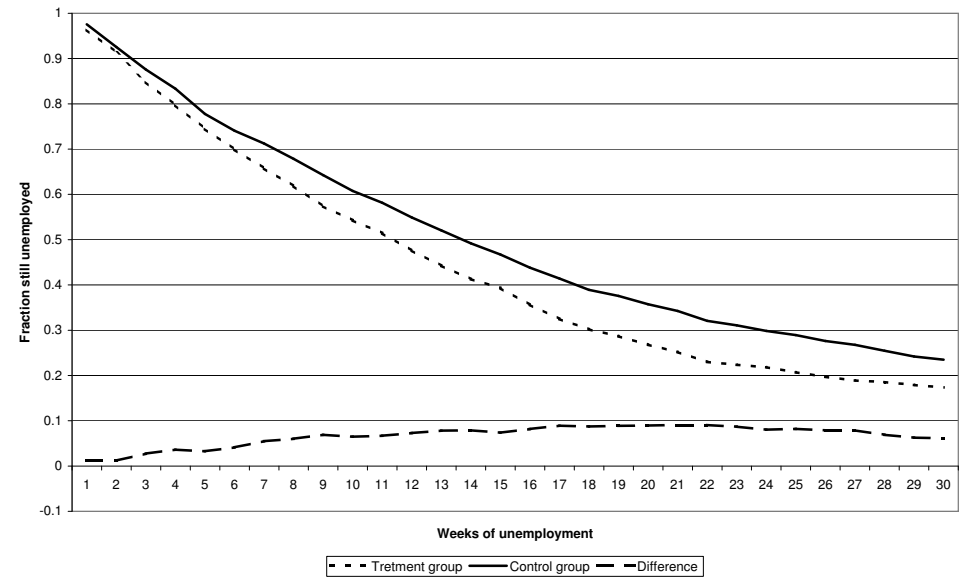


Fig. 3: Difference between survivor functions of the treatment group and the control group

a. South Jutland

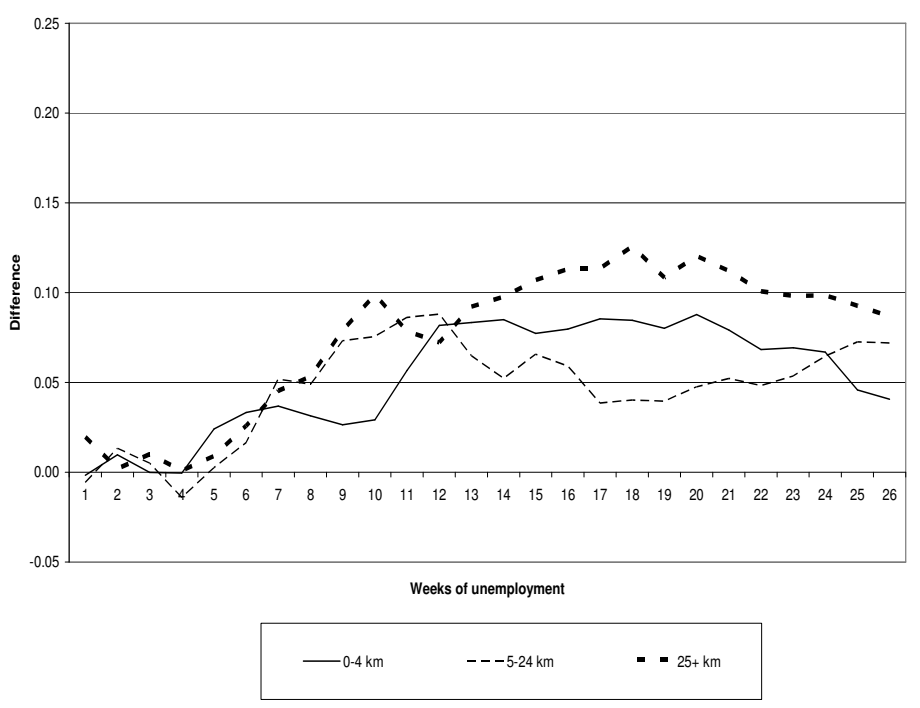

b. Storstrøm

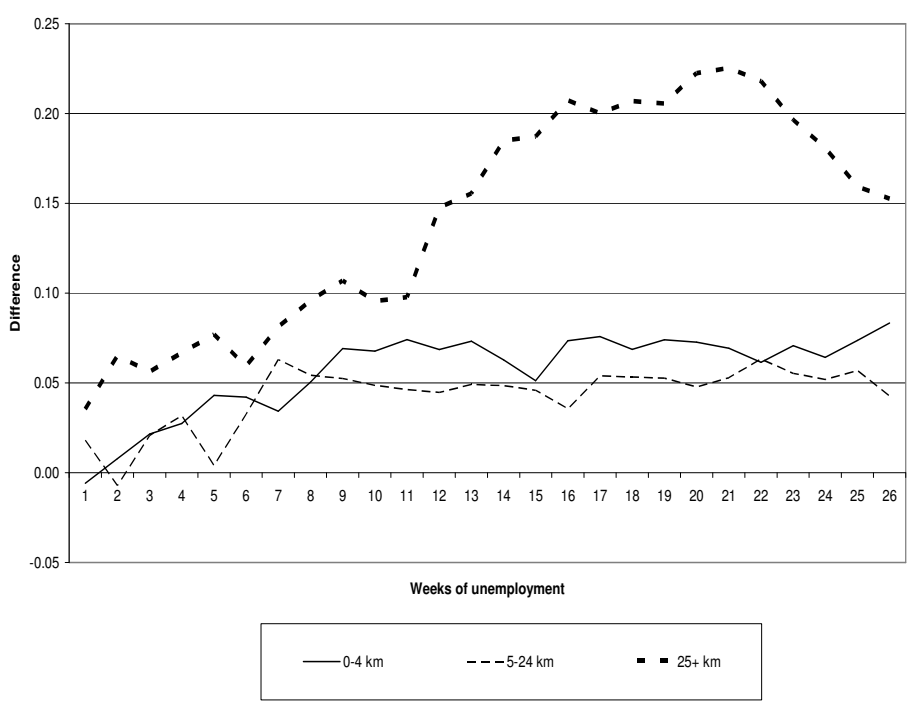


Fig. 4: Fraction of job finders who remain employed by weeks of employment

a. South Jutland

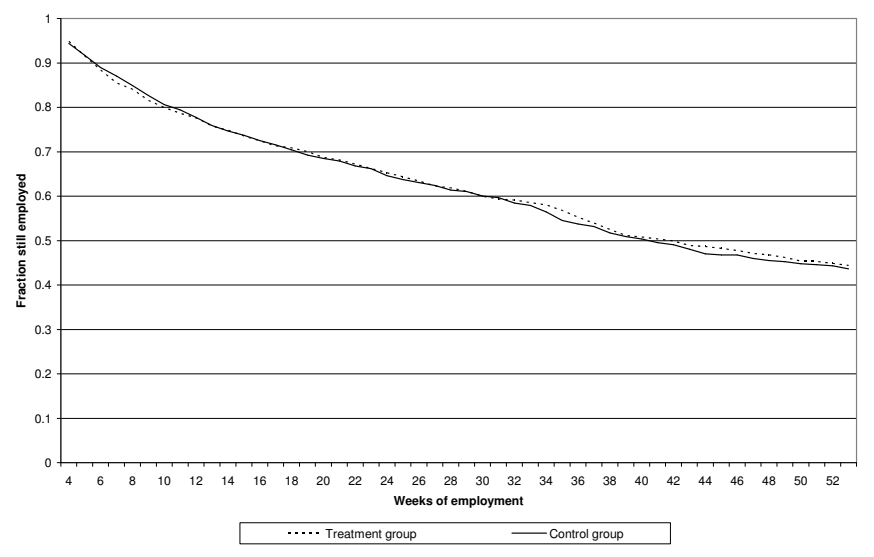

b. Storstrøm

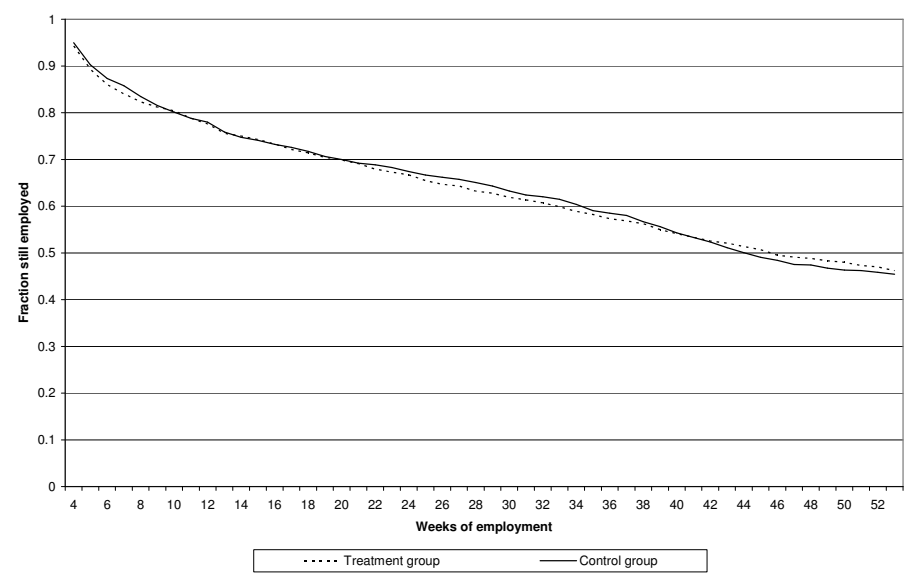


Tab. 7: Characteristics by region

\begin{tabular}{|c|c|c|c|c|c|c|}
\hline & \multicolumn{3}{|c|}{ South Jutland } & \multicolumn{3}{|c|}{ Storstrøm } \\
\hline & $0-4 \mathrm{~km}$ & $5-24 \mathrm{~km}$ & $25+\mathrm{km}$ & $0-4 \mathrm{~km}$ & $5-24 \mathrm{~km}$ & $25+\mathrm{km}$ \\
\hline Treatment & 0.48 & 0.50 & 0.50 & 0.48 & 0.49 & 0.52 \\
\hline Male & 0.53 & 0.54 & 0.54 & 0.59 & 0.63 & 0.61 \\
\hline Age 18-29 (ref) & 0.34 & 0.24 & 0.21 & 0.27 & 0.17 & 0.21 \\
\hline Age $30-39$ & 0.23 & 0.25 & 0.26 & 0.26 & 0.25 & 0.24 \\
\hline Age $40-49$ & 0.24 & 0.26 & 0.27 & 0.25 & 0.25 & 0.23 \\
\hline Age $50+$ & 0.19 & 0.26 & 0.26 & 0.22 & 0.33 & 0.32 \\
\hline Blue collar (ref) & 0.30 & 0.37 & 0.34 & 0.37 & 0.42 & 0.43 \\
\hline Occupation 1 & 0.04 & 0.02 & 0.02 & 0.03 & 0.01 & 0.02 \\
\hline Occupation 2 & 0.09 & 0.07 & 0.05 & 0.09 & 0.06 & 0.06 \\
\hline Occupation 3 & 0.08 & 0.08 & 0.07 & 0.07 & 0.07 & 0.06 \\
\hline Occupation 4 & 0.12 & 0.07 & 0.09 & 0.12 & 0.11 & 0.07 \\
\hline Occupation 5 & 0.05 & 0.05 & 0.08 & 0.02 & 0.04 & 0.06 \\
\hline Occupation 6 & 0.15 & 0.16 & 0.18 & 0.10 & 0.10 & 0.10 \\
\hline Occupation 7 & 0.06 & 0.07 & 0.08 & 0.08 & 0.06 & 0.07 \\
\hline Occupation 8 & 0.05 & 0.05 & 0.05 & 0.05 & 0.05 & 0.05 \\
\hline Occupation 9 & 0.02 & 0.02 & 0.01 & 0.03 & 0.03 & 0.04 \\
\hline Occupation 10 & 0.04 & 0.04 & 0.02 & 0.03 & 0.04 & 0.04 \\
\hline Danes (ref) & 0.90 & 0.94 & 0.93 & 0.91 & 0.96 & 0.96 \\
\hline Immigrants western & 0.03 & 0.03 & 0.04 & 0.02 & 0.01 & 0.01 \\
\hline Immigrants non-western & 0.06 & 0.03 & 0.03 & 0.07 & 0.03 & 0.03 \\
\hline Previous unemployed 1 & 0.20 & 0.19 & 0.21 & 0.22 & 0.20 & 0.22 \\
\hline Previous unemployed 2 & 0.25 & 0.25 & 0.25 & 0.26 & 0.26 & 0.26 \\
\hline Previous unemployed 3 & 0.26 & 0.25 & 0.26 & 0.27 & 0.26 & 0.27 \\
\hline Excluded member & 0.00 & 0.01 & 0.01 & 0.03 & 0.02 & 0.03 \\
\hline Experience $0-5$ years (ref) & 0.32 & 0.21 & 0.18 & 0.23 & 0.13 & 0.16 \\
\hline Experience 5-10 years & 0.21 & 0.21 & 0.22 & 0.21 & 0.16 & 0.20 \\
\hline Experience $10-15$ years & 0.16 & 0.17 & 0.16 & 0.16 & 0.17 & 0.19 \\
\hline Experience $15-20$ years & 0.11 & 0.13 & 0.17 & 0.12 & 0.16 & 0.14 \\
\hline Experience 20+ years & 0.19 & 0.28 & 0.27 & 0.28 & 0.39 & 0.31 \\
\hline Single (ref) & 0.42 & 0.25 & 0.31 & 0.37 & 0.28 & 0.35 \\
\hline Married & 0.36 & 0.52 & 0.50 & 0.40 & 0.50 & 0.40 \\
\hline Cohabiting & 0.22 & 0.23 & 0.19 & 0.23 & 0.22 & 0.25 \\
\hline Children & 0.33 & 0.41 & 0.42 & 0.36 & 0.41 & 0.36 \\
\hline Primary and lower sec (ref) & 0.26 & 0.33 & 0.34 & 0.27 & 0.32 & 0.32 \\
\hline No educational information & 0.06 & 0.05 & 0.06 & 0.05 & 0.03 & 0.04 \\
\hline Upper secondary school & 0.03 & 0.02 & 0.02 & 0.04 & 0.02 & 0.03 \\
\hline Vocational education & 0.45 & 0.49 & 0.45 & 0.46 & 0.52 & 0.49 \\
\hline Short further education & 0.05 & 0.04 & 0.04 & 0.04 & 0.04 & 0.03 \\
\hline Long further education & 0.12 & 0.07 & 0.07 & 0.12 & 0.06 & 0.07 \\
\hline Higher education & 0.02 & 0.01 & 0.01 & 0.03 & 0.01 & 0.01 \\
\hline $\mathrm{N}$ & 662 & 740 & 703 & 946 & 993 & 429 \\
\hline
\end{tabular}

